\title{
DESKRIPSI TENTANG KONDISI KEHIDUPAN SOSIAL EKONOMI MASYARAKAT TERHADAP INDUSTRI BATU MERAH DI DESA KALIBU KECAMATAN KULISUSU KABUPATEN BUTON UTARA
}

\author{
Irta Hidayat ${ }^{1}$, Ramli $^{2}$ \\ ${ }^{1}$ Alumni Pendidikaan Geografi FKIP UHO \\ ${ }^{2}$ Dosen pendidikan Geografi FKIP UHO
}

\begin{abstract}
Abstrak: Penelitian ini berjudul" Deskripsi tentang kondisi sosial ekonomi masyarakat terhadap industri batu merah di Desa Kalibu Kecamatan Kulisusu Kabupaten Buton Utara". Penelitian ini bertujuan untuk mendeskripsikan kondisi kehidupan sosial, mendeskripsikan kondisi kehidupan ekonomi warga masyarakat, dan mendeskripsikan kondisi kehidupan sosial ekonomi warga masyarakat di Desa Kalibu Kecamatan Kulisusu kaitannya dengan industri batu merah. Berdasarkan hasil penelitian dari 29 orang sebagai responden menunjukkan bahwa terdapat 62,07\% tingkat pendidikan informan adalah tamatan SD dan SMP, 34,48 \% adalah tamatan SMA (sederajat). Pendidikan yang mereka miliki hanya 33,03 \% yang menunjang pekerjaan. Kondisi tempat tinggal mengalami perubahan/membaik setelah informan menekuni pekerjaan sebagai industri batu merah. Kesehatan anggota keluarga membaik setelah menekuni pekerjaan industri batu merah. Disamping itu kemudahan mendapatkan pelayanan kesehatan juga tergolong membaik karena informan lebih memilih Puskesmas terdekat untuk melakukan pengobatan, walaupun mengeluarkan sejumlah dana. Pendapatan informan sebelum menekuni industri batu merah tidak lebih dari $\mathrm{Rp}$ 1.500.000, dan setelah menekuni industri batu merah pendapatan netto mencapai Rp 3.000.000,- setiap bulannya. Konsumsi atau pengeluaran rumah tangga rata-rata $\mathrm{Rp} 2.000 .000$, tiap bulannya. Dengan demikian maka warga masyarakat Desa Kalibu Kecamatan Kulisusu Kabupaten Buton Utara setelah menekuni pekerjaan industri batu merah kondisi sosial ekonomi mengalami perubahan ke arah yang lebih baik.
\end{abstract}

Kata Kunci : Kondisi Sosial Ekonomi, Industri Batu Merah 


\title{
DESCRIPTION OF SOCIAL ECONOMY CONDITION TO BRICK INDUSTRY IN KALIBU VILLAGE KULISUSU SUB-DISTRICT OF NORTH BUTON REGENCY
}

\author{
Irta Hidayat ${ }^{1}$, Ramli $^{2}$ \\ ${ }^{1}$ Geography Educational Alumni Halu Oleo University \\ ${ }^{2}$ Geography education lecturer at Halu Oleo University
}

\begin{abstract}
This research entitled "Description of society social economy condition to brick industry in Kalibu Village Kulisusu Sub-district of North Buton Regency". This study aims to describe the condition of social life, describe the condition of economic life of citizens, and describe the condition of socio-economic life of citizens in the village Kalibu Kulisusu District relation to the brick industry. Based on the results of research from 29 people as respondents indicate that there are $62.07 \%$ informants education level is elementary and junior high school, $34.48 \%$ is high school graduate (equal). The education they have only $33.03 \%$ that support the work. The condition of the residence has changed / improved after the informant pursue the job as a red stone industry. Health of family members improved after pursue the work of the red stone industry. Besides, the ease of getting health service is also better because the informants prefer the nearest Puskesmas to do the treatment, even though it issued some funds. Informant's income before pursue the red stone industry is not more than $\mathrm{Rp} 1,500,000$, and after pursue the red stone industry net income reaches $\mathrm{Rp}$ $3,000,000$ per month. The average household consumption or expenditure is $\mathrm{Rp}$ 2,000,000 per month. Thus, residents of Kalibu Village Kulisusu Sub-district, North Buton Regency after pursue the work of red stone industry socio-economic conditions changed to a better direction.
\end{abstract}

\section{Keywords: Socio-Economic Condition, Brick Industry}

\section{PENDAHULUAN}

Pada dasarnya pemerintah terus berusaha membangun sistem perekonomian bangsa untuk memenuhi tingkat kesejahteraan masyarakat. Dalam membangun berbagai sektor, pembangunan sektor ekonomi sebaiknya lebih dikedepankan karena masalah ekonomi ini memegang peranan penting dalam kehidupan masyarakat, apalagi masyarakat yang berdomisili di kawasan perdesaan seperti yang terdapat di Kecamatan Ereke Kabupaten Buton Utara.

\begin{abstract}
Beberapa pakar ekonomi antara lain mengatakan bahwa kehidupan individu dalam masyarakat sangat didasarkan pada asas ekonomi, institusi politik, pendidikan, ilmu pengetahuan, dan sebagainya tergantung pada persediaan sumbersumber ekonomi untuk kelangsungan hidupnya; Artinya bahwa institusiinstitusi tersebut tidak dapat berkembang tanpa dukungan ekonomi yang mapan.
\end{abstract}

Menurut Nasution (1995) mengatakan bahwa kehidupan sosial merupakan suatu proses sosial dalam masyarakat yang mempunyai jangkauan sangat luas dan dapat 
meliputi seluruh manusia yang terdiri atas berbagai kelompok baik kelompok besar maupun kelompok kecil atau tergantung jumlah anggotanya yakni minimal berjumlah dua orang. Artinya bahwa dalam melakukan aktivitas yang berkaitan dengan kehidupan sosial selalu dilakukan secara kelompok bukan secara perorangan atau individu.

Pembuatan batu merah atau batu bata umumnya dilakukan oleh warga masyarakat yang berjenis kelamin laki-laki dengan peralatan sederhana dan memerlukan bahan bakar berupa kayu batangan yang relatif memadai/banyak. Dengan memahami teknik pembakaran batu merah yang baik maka hasil dari pembakaran tersebut umumnya memiliki kualitas yang baik pula. Pekerjaan ini telah dilakukan warga masyarakat Desa Kalibu Kecamatan Kulisusu sekitar 20 tahun terakhir.

Mengacu dari pengamatan awal dari peneliti yang telah dilakukan selama beberapa bulan terdahulu, maka peneliti merasa tertarik untuk mencari tahu mengapa warga masyarakat yang berdomisili di Desa Kalibu cenderung memilih profesi (pekerja) sebagai pembuat batu merah atau batu bata.

Soekanto (1983) mengatakan bahwa istilah sosial sebagai suatu yang berkenaan dengan interpersonal yang berkaitan dengan proses sosial. Selanjutnya dikatakan pula bahwa pola interaksi merupakan kunci dari semua kegiatan sosial. Oleh karena itu tanpa ada interaksi tidak mungkin ada suatu kehidupan bersama. Dengan demikian maka interaksi sosial merupakan dasar dari proses sosial yang dinamis dalam masyarakat (Nurmita, 2009).

Kata sosial diartikan sebagai sesuatu yang berkenaan atau yang berhubungan dengan manusia, baik secara individu, antar individu maupun secara kelompok. Hubungan antar individu tersebut dilakukan melalui proses interaksi. Seperti yang dikatakan Nasikum (2003) bahwa suatu sistem sosial pada dasarnya tidak lain adalah suatu sistem dari pada tindakan-tindakan.

Berangkat dari beberapa pokok pemikiran di atas maka sosial ekonomi dalam penelitian ini adalah keadaan seseorang atau suatu masyarakat mengenai keadaan sosial ekonomi yang mencakup tingkat pendidikan, keadaan kesehatan, keadaan perumahan dan pendapatan serta jenis mata pencaharian.

Purwanto (1987) mengatakan bahwa pendidikan adalah segala usaha orang dewasa dalam pergaulannya dengan anak-anak untuk memimpin perkembangan jasmani dan rohaninya ke arah kedewasaan atau pendidikan adalah pimpinan yang diberikan dengan sengaja oleh orang dewasa kepada anak-anak dalam pertumbuhan (pertumbuhan jasmani dan rohani) agar berguna bagi diri sendiri dan bagi masyarakat.

Konsep kesehatan menurut Organisasi Kesehatan Dunia (WHO) tahun 1948 dikatakan bahwa kesehatan adalah sebagai "suatu keadaan fisik, mental dan sosial kesejahteraan dan bukan hanya ketiadaan penyakit atau kelemahan". Pada tahun 1986 WHO dalam piagam Ottawa untuk promosi kesehatan mengatakan bahwa pengertian kesehatan adalah 
"sumberdaya bagi kehidupan seharihari, bukan tujuan hidup kesehatan adalah konsep positif menekankan sumberdaya, sosial, dan pribadi serta kemampuan fisik". Winsolow dalam Sarwoto (2002) mengatakan bahwa kesehatan masyarakat adalah ilmu dan seni yang bertujuan untuk mencegah timbulnya penyakit, memperpanjang masa hidup dan mempertinggi nilainilai kesehatan.

$\begin{array}{lcr} & \text { Menurut Badan Pusat Statistik } \\ \text { (2001) bahwa pada } & \text { dasarnya } \\ \text { perumahan menyangkut } & \text { kebutuhan } \\ \text { dasar } & \text { manusia } & \text { sebagai }\end{array}$
pengejawantahan diri pribadi maupun kelompok dalam bertempat tinggal dan bermukim sertas merupakan tempat membina dan membentuk manusia menjadi manusia berkepribadian dan berkebudayaan. Dengan kata lain perumahan merupakan indikator dari mutu kehidupan dan kesejahteraan masyarakat. Kondisi perumahan yang belum memenuhi persyaratan teknis dan kesehatan disebabkan oleh tingkat pendapatan, pengetahuan dan pendidikan masyarakat yang relatif rendah.

Selanjutnya BPS menjelaskan
bahwa indikator kesejahteraan
masyarakat dapat dilihat dari kondisi
perumahan mengenai status
kepemilikan rumah, pondasi rumah,
lantai rumah, dinding, plafon dan atap
rumah. Disamping itu ciri-ciri tentang
jenis rumahg layak huni yang dipilah
adalah rumah permanen yang terdiri
dari pondasi yang terbuat dari beton,
dinding tembok, atap seng
berlantaikan flour dan plafonya terbuat
dari nilon dan jenis rumah darurat ciri-
ciri yang digambarkan adalah pondasi
yang terbuat dari tanah, dinding yang
terbuat dari anyaman bambu, atap

yang terbuat dari daun, lantai tanah dan tidak memiliki plafon.

Winardi (1992) mengatakan bahwa pendapatan adalah hasil berupa uang atau hasil materi lainnya yang dicapai dari penggunaan kekayaan atau jasa-jasa manusia bebas. Pendapat lain mengatakan bahwa pendapatan adalah arus masuk bruto manfaat ekonomi yang timbul dari aktivitas normal perusahan selama periode yang mengakibatkan kenaikkan ekuitas, yang tidak berasal dari kontribusi penanaman modal. Pendapatan hanya terdiri dari arus masuk bruto manfaat ekonomi yang diterima oleh perusahan untuk dirinya sendiri. Jumlah yang ditagih untuk dan atau atas nama pihak ketiga bukan merupakan pendapatan, karena tidak menghasilkan manfaat ekonomi perusahan dan tidak mengakibatkan kenaikkan ekuitas (Ikatan Akutan Indonesia, 2007).

Sukirno (2003) memberikan batasan tentang istilah ekonomi yang dapat dikemukakan sebagai berikut : Ekonomi berasal dari bahasa Yunani dua kata, yaitu "oikos" artinya rumah dan "nomos" artinya ilmu pengetahuan. Jadi, ekonomi diartikan sebagai aturan-aturan dalam rumah tangga. Ia merengkan tentang prinsipprinsip di dalam menggunakan pendapatan rumah tangga. Selanjutnya ia mengatakan bahwa ekonomi adalah suatu tindakan atau kegiatan yang berkaitan dengan penciptaan barang atau jasa yang dibuat untuk memenuhi kebutuhan manusia.

Soekanto (1988) mengatakan bahwa sosial ekonomi adalah posisi seseorang dalam masyarakat berkaitan dengan orang lain dalam arti lingkungan pergaulan, prestasinya, dan 
hak-hak serta kewajiban dalam hubungannya dengan sumberdaya. Sejalan dengan itu, Abdulsyani (2001) mengatakan bahwa sosial ekonomi adalah kedudukan atau posisi seseorang dalam kelompok manusia yang ditentukan oleh jenis aktivitas ekonomi, pendapatan, tingkat pendidikan, jenis rumah tinggal, dan jabatan dalam organisasi.

Mac Iver Page dalam Soerjono Soekanto (1990) mengatakan bahwa "suatu sistem dan suatu kebiasaan dan tata cara dari wewenang, dari kerja sama antara berbagai kelompok dan pengelompokan dari pengawasan tingkah laku serta kebebasankebebasan manusia. Keseluruhan yang berubah-ubah masyarakat merupakan jalinan hubungan sosial dan masyarakat selalu berubah-ubah".

D. Hendropuspito C.C. (1989) memberi definisi bahwa masyarakat adalah kesatuan yang tetap dari orangorang yang hidup di daerah tertentu dan bekerja sama dalam kelompokkelompok berdasarkan kebudayaan yang sama untuk mencapai kepentingan yang sama.

\section{METODE PENELITIAN Tempat dan waktu penelitian}

Penelitian ini telah di laksanakan di Desa Kalibu Kecamatan Kulisusu Kabupaten Buton Utara dan diprakirakan memakan waktu selama dua bulan atau setara dengan 60 hari kerja.

\section{Populasi dan Sampel}

Mengacu dari hasil observasi awal di lokasi penelitian menunjukkan bahwa warga masyarakat yang menekuni pekerjaan sebagai penambang batu merah kurang lebih 60 orang yang hingga saat ini masih aktif dan berdomisili di Desa Kalibu Kecamatan Kulisusu. Dengan demikian sampel dalam penelitian ini berjumlah 30 responden.

\section{Jenis dan Sumber Data}

Jenis data yang dimaksud dalam penelitian ini terdiri atas dua macam, yaitu :

a. Data primer.

b. Data sekunder.

\section{Teknik Pengumpulan Data}

Dalam proses pengumpulan data penelitian, peneliti menggunakan beberapa cara yang lazim digunakan oleh peneliti lainnya, yaitu : 1) Observasi atau pengamatan, 2) Wawancara atau interview, 3) Angket atau Quesioner

\section{Teknik Analisis Data}

Data penelitian yang telah terkumpul selanjutnya diolah dengan analisis secara kuantitatif dan menggunakan rumus sebagai berikut :

$$
\mathrm{P}=\frac{F}{N} \times 100 \%
$$

(Mukhtar dan

Erna Widodo, 2000)

$$
\begin{aligned}
\text { dimana } & : \\
\mathrm{P} & =\text { Kategori; } \\
\mathrm{F} & =\text { Frekuensi responden yang } \\
& \text { memilih alternatif jawaban } \\
& \text { sama; } \\
\mathrm{N} & =\text { Jumlah responden; } \\
\% & =\text { Persentase; } \\
& \text { Untuk menghitung rata-rata }
\end{aligned}
$$
skor setiap indikator di gunakan rumus sebagai berikut : 


$$
\bar{X}=\frac{a_{1} f_{1}+a_{2} f_{2}+a_{3} f_{3}+\ldots \ldots \ldots+a_{n} f_{n}}{n}
$$

(Soemantri, Dkk., 2006)

$$
\begin{aligned}
& \text { dimana : } \\
& \bar{X} \quad=\text { Rata-rata } \\
& a_{n} \quad=\text { Kategori yang ke-n } \\
& f_{n} \quad=\text { Frekuensi yang ke-n } \\
& \mathrm{n} \quad=\text { Jumlah responden }
\end{aligned}
$$

\section{GAMBARAN UMUM LOKASI PENELITIAN}

\section{Sejarah Singkat}

Desa Kalibu tempo dulu merupakan sebidang lahan hutan belantara yang tiba-tiba dijadikan sebagai lahan pertanian yang didiami oleh sekelompok anggota warga masyarakat saja. Dari waktu ke waktu mulai kedatangan kelompok kecil warga masyarakat untuk membuka lahan perkebunan baru dan tinggal menetap di tempat tersebut hingga menjadi perkampungan kecil.

\section{Administrasi}

Wilayahadministrasi Desa Kalibu memiliki luas sekitar 454,89 ha. Secara geografis, Desa Kalibu Kecamatan Kulisusu Kabupaten Buton Utara Provinsi Sulawesi Tenggara terletak pada Lat Lon $\left(123^{\circ} 10.26\right.$ BT dan $4^{\circ} 35.89$ LS) / WGS 84 UTM Zone 51S X : $0519632 \quad \mathrm{Y}$ : 9473832 .

\section{Demografis}

Secara demografis, Desa Kalibu Kecamatan Kulisusu Kabupaten Buton Utara tercatat jumlah penduduknya sebanyak 938 jiwa. Jumlah tersebut terbagi atas 488 jenis kelamin laki-laki, dan 450 jiwa berjenis kelamin perempuan, dan terdiri atas 258 Kepala Keluarga (KK). Data tentang jumlah penduduk Desa Kalibu dapat dilihat pada Tabel 3.1. berikut:

Tabel 3.1. Jumlah Penduduk Desa Kalibu Tahun 2018

\begin{tabular}{ccccc}
\hline No & Jenis Kelamin & Dusun I & Dusun II & $\begin{array}{c}\text { Jumlah } \\
\text { (dlm Jiwa) }\end{array}$ \\
\hline 1 & Laki - laki & 253 & 235 & 488 \\
\hline 2 & Perempuan & 230 & 220 & 450 \\
\hline & Tot a l & 485 & 455 & 938 \\
\hline
\end{tabular}

Sumber: Rekapitulasi Hasil Pendataan Keluarga tahun 2018

Tabel 3.2. Jumlah Penduduk Desa Kalibu Menurut Kelompok Usia

\begin{tabular}{cccccc}
\hline No & $\begin{array}{c}\text { Kelompok Usia } \\
(\text { dlm Tahun })\end{array}$ & Dusun I & Dusun II & $\begin{array}{c}\text { Jumlah } \\
\text { (dlm Jiwa) }\end{array}$ \\
\hline 1 & $0-<$ & 12 & 12 & 24 \\
\hline 2 & 1 & $-<5$ & 46 & 26 & 72 \\
\hline 3 & 5 & $-<10$ & 52 & 46 & 98 \\
\hline 4 & $10-<25$ & 152 & 142 & 294 \\
\hline 5 & $25-<60$ & 196 & 196 & 392 \\
\hline 6 & $\geq 60$ & 33 & 31 & 64 \\
\hline \multicolumn{7}{c}{ To t a 1} & 491 & 453 & 944 \\
\hline
\end{tabular}

Sumber: Rekapitulasi Hasil Pendataan Keluarga Tahun 2018 


\section{Pendidikan}

Secara umum Desa Kalibu Kecamatan Kulisusu memiliki jenjang atau tingkat pendidikan sebagaimana disajikan oleh Tabel 3.3 berikut :

Tabel 3.3. Rata-rata Tingkat Pendidikan Warga Masyarakat Desa Kalibu

\begin{tabular}{clcc}
\hline No & \multicolumn{1}{c}{ Jenjang Pendidikan } & $\begin{array}{c}\text { Jumlah } \\
\text { (dlm Jiwa) }\end{array}$ & $\begin{array}{c}\text { Persentase } \\
(\%)\end{array}$ \\
\hline 1 & $\begin{array}{l}\text { Tidak sekolah atau belum tamat Sekolah } \\
\text { Dasar }\end{array}$ & 231 & 24,63 \\
\hline 2 & Tamat SD atau sederajat & 285 & 30,38 \\
\hline 3 & Tamat SMP atau sederajat & 148 & 15,78 \\
\hline 4 & Tamat SMA atau Sederajat & 245 & 26,12 \\
\hline 5 & Jenjang Diploma & 4 & 0,43 \\
\hline 6 & Strata - II & 1 & 0,10 \\
\hline & T o t a l & 938 & 100
\end{tabular}

Sumber: Rekapitulasi Hasil Pendataan Keluarga Tahun 2018

Selanjutnya jenjang pendidikan menurut kepala keluarga sebagaimana disajikan oleh Tabel 3.4 berikut :

Tabel 3.4. Status Pendidikan Menurut Kepala Keluarga

\begin{tabular}{clccc}
\hline No & Status Pendidikan & Dusun I & Dusun II & Jumlah \\
\hline $\mathbf{1}$ & Tidak tamat SD & 34 & 30 & 63 \\
\hline $\mathbf{2}$ & Tamat SD - SLTP & 52 & 45 & 97 \\
\hline $\mathbf{3}$ & Tamat SLTA & 40 & 40 & 80 \\
\hline $\mathbf{4}$ & Tamat Akademi / Perguruan Tinggi & 6 & 11 & 17 \\
\hline & T o t a l & $\mathbf{1 3 2}$ & $\mathbf{1 2 6}$ & $\mathbf{2 5 8}$
\end{tabular}

Sumber: Rekapitulasi Hasil Pendataan Keluarga Tahun 2017

Mata Pencaharian

Secara umum warga

masyarakat yang berdomisili di wilayah Desa Kalibu Kecamatan
Kulisusu mempunyai berbagai macam atau jenis mata pencaharian, seperti yang disajikan oleh Tabel 3.5 berikut 
Tabel 3.5. Jenis Mata Pencaharian Pokok di Desa Kalibu

\begin{tabular}{clc}
\hline No & \multicolumn{1}{c}{ Jenis Pekerjaan } & Jumlah \\
\hline $\mathbf{1}$ & Petani / Buruh Tani & 146 \\
\hline $\mathbf{2}$ & Pekebun & 75 \\
\hline $\mathbf{3}$ & Nelayan & 16 \\
\hline $\mathbf{4}$ & PNS / TNI / POLRI & 24 \\
\hline $\mathbf{5}$ & Pedagang & 17 \\
\hline $\mathbf{6}$ & Tukang (Pembuat) Batu Merah & 66 \\
\hline $\mathbf{7}$ & Tukang Bangunan & 5 \\
\hline $\mathbf{8}$ & Tukang Campuran & 268 \\
\hline $\mathbf{9}$ & Tidak Bekerja / Pengangguran & 23 \\
\hline & T ot a l & $\mathbf{6 4 0}$ \\
\hline
\end{tabular}

Sumber : Pendataan Desa Kalibu Tahun 2018

Berdasarkan muatan unsur yang terdapat pada Tabel 3.5 di atas dapat dikatakan bahwa paling tidak ada 7 (tujuh) jenis mata pencaharian yang dapat dimanfaatkan warga masyarakat dalam menopang kelangsungan hidup pada umumnya.
Agama

Seperti yang dialami oleh Desa-Desa lain di daerah lain, Desa Kalibu Kecamatan Kulisusu terdapat pula sejumlah agama, namun tidak sampai berkembang sehingga kepemelukan agama tertentu di Desa Kalibu belum teridentifikasi secara baik seperti yang disajikan oleh Tabel 3.6 berikut :

Tabel 3.6. Persentase Penduduk Desa Kalibu Berdasarkan Agama

\begin{tabular}{|c|c|c|c|}
\hline No & Jenis Agama & Jumlah (dlm Jiwa) & Persentase (\%) \\
\hline 1 & Islam & 983 & 100,00 \\
\hline 2 & Katholik & 0 & 0 \\
\hline 3 & Protestan & 0 & 0 \\
\hline 4 & Hindu & 0 & 0 \\
\hline 5 & Budha & 0 & 0 \\
\hline & Total & 983 & 100,00 \\
\hline
\end{tabular}

Sumber : Data Statistik Desa Kalibu tahun 2018

\section{Perkebunan}

Ada dua macam perkebunan yang berkembang di Desa Kalibu Kecamatan Kulisusu Kabupaten Buton Utara. Antara lain berikut :

1. Perkebunan Jambu Mette

2. Perkebunan Kelapa

\section{Industri}

Salah satu kegiatan atau aktivitas warga masyarakat yang paling menonjol setiap hari di Desa Kalibu adalah usaha industri batu merah. Kemampuan warga masyarakat Desa Kalibu dalam mencetak batu merah bisa mencapai 300 biji per hari setiap orang. Mereka 
melakukan kegitan ini dapat secara kelompok tapi dapat pula dilakukan secara perorangan.

Kegiatan ini dilakukan karena tersedianya sumberdaya lahan berupa tanah yang bersifat plastis (liatan) relatif menunjang, sehingga batu merah yang sudah tercetak tinggal menunggu saat pembakaran yang biasanya menggunakan berbagai jenis kayu sebagai bahan bakarnya. Batu merah digunakan sebagai bahan untuk membuat dinding bangunan/atau rumah, baik rumah penduduk maupun gedung-gedung milik swasta/atau pemerintah. Hampir semua bangunan yang terdapat di Kabupaten Buton Utara menggunakan batu merah yang umumnya diproduksi di Desa Kalibu. Nilai jual batu merah yang siap pakai setiap kubiknya dengan harga $\pm \mathrm{Rp}$ 500.000,-

\section{Pariwisata}

Ada dua kegiatan wisata yang bisa dilakukan di wilayah Desa Kalibu, yaitu :

a. Tracking Mangrove

b. Wisata Budaya

\section{HASIL PENELITIAN Keadaan Pendidikan}

Pada penelitian ini, penulis mengemukakan kondisi pendidikan di Desa Kalibu Kecamatan Kulisusu Kabupaten Buton Utara meliputi 2 (dua) unsur yaitu (1) tingkat pendidikan yang dimiliki, dan (2) jenjang pendidikan yang menunjang pekerjaan, seperti disajikan oleh Tabel 5.1. dan Tabel 5.2.

Tabel 4.1. Pendidikan Terakhir Yang Dimiliki Responden

\begin{tabular}{clccc}
\hline No & \multicolumn{1}{c}{ Variabel } & Frekuensi (F) & Persentase (\%) \\
\hline \multirow{3}{*}{1} & a. SD dan SMP atau sederajat (tamat) & 18 & 62,07 \\
\cline { 2 - 5 } & b. SMA atau sederajat (tamat) & 10 & 34,48 \\
\cline { 2 - 5 } & c. Perguruan tinggi (tamat) & 1 & 3,45 \\
\hline \multicolumn{2}{c}{ Total } & 29 & 100,00 \\
\hline
\end{tabular}

Sumber : Data yang di olah peneliti tahun 2018

Tabel 4.1. di atas memperlihatkan bahwa terdapat 18 orang atau sekitar $62,07 \%$ informan yang berprofesi sebagai pembuat batu merah umumnya memiliki pendidikan terakhir SD dan SMP. Informan yang memiliki pendidikan terakhir setingkat SMA atau sederajat sebesar 10 orang atau sekitar $34,48 \%$. Sisanya sebesar 1 orang atau $3,45 \%$ informan berpendidikan terakhir di perguruan tinggi.

Tabel 4.2. Jenjang Pendidikan Yang Di Peroleh

\begin{tabular}{ccccc}
\hline No & \multicolumn{1}{c}{ Variabel } & $\begin{array}{c}\text { Frekuensi } \\
(\mathrm{F})\end{array}$ & $\begin{array}{c}\text { Persentase } \\
(\%)\end{array}$ \\
\hline \multirow{2}{*}{2} & a. & $\begin{array}{l}\text { Dapat menunjang profesi sebagai pembuat } \\
\text { batu merah }\end{array}$ & 9 & 31,03 \\
\cline { 2 - 5 } & b. & $\begin{array}{l}\text { Tidak menunjang profesi sebagai pembuat } \\
\text { batu merah }\end{array}$ & 16 & 55,17 \\
\cline { 2 - 5 } & \multicolumn{2}{c}{ Ragu - ragu } & 4 & 13,80 \\
\hline \multicolumn{2}{c}{ Total } & 29 & 100,00 \\
\hline
\end{tabular}

Sumber : Data yang di olah peneliti tahun 2018 
Terkait dengan pekerjaan yang mereka tekuni, menunjukkan bahwa jenjang pendidikan informan yang menunjang profesi sebagai pembuat batu merah menyatakan menunjang, sekitar $31,03 \%$ atau ada 9 orang. Sebanyak 16 orang atau sekitar 55,17 $\%$ menyatakan tidak menunjang, dan sisanya sebanyak 4 oarng atau $13,80 \%$ menyatakan ragu-ragu.

\section{Kondisi Kesehatan Responden}

Untuk mengetahui kondisi
kesehatan responden peneliti
pengemukakan item pernyataan
sebagaimana disajikan oleh Tabel 4.3 ;
Tabel 4.4; Tabel 4.5 ; Tabel 4.6 ; dan
Tabel 4.7 yang secara berturut-turut
dapat dikemukan sebagai berikut :

Tabel. 4.3.

Dalam Selang Waktu 6 Bulan Terakhir Anda Mengalami Sakit Badan

\begin{tabular}{|c|c|c|c|}
\hline No & Variabel & $\begin{array}{c}\text { Frekuensi } \\
(\mathrm{F})\end{array}$ & $\begin{array}{c}\text { Persentase } \\
(\%)\end{array}$ \\
\hline \multirow{3}{*}{3} & a. Pernah & 15 & 51,72 \\
\hline & b. Tidak pernah & 14 & 48,28 \\
\hline & c. Ragu-ragu & - & - \\
\hline & Total & 29 & 100,00 \\
\hline
\end{tabular}

Sumber : Data yang di olah peneliti tahun 2018

Pada bidang kesehatan responden ditemukan bahwa dalam selang waktu 6 bulan terakhir informan pernah mengalami sakit badan sebanyak 15 orang atau sekitar $51,72 \%$. Berdasarkan hasil wawancara yang dilakukan penelitian diperoleh keterangan bahwa responden yang mengalami sakit disebabkan oleh kelelahan badan saat melakukan pekerjaan dan bukan berasal dari faktor lain.

Ungkapan wawancara yang peneliti kemukakan adalah sebagai berikut berikut : Menurut perasaan atau pemikiran Anda, "Apakah kesakitan yang Anda alami itu disebabkan oleh serangan penyakit yang datang secara tiba-tiba ?
Ataukah disebabkan oleh kelelahan Anda saat menekuni pekerjaan ini? Ataukah faktor lain yang tidak dapat dijangkau oleh alam pikiran manusia ?" Berapa lama penyakit yang menimpah Anda, (1 s.d. 2 hari, 3 s.d. 4 hari, lebih besar dari 5 hari).

Tabel 5.3. di atas memperlihatkan bahwa informan belum atau tidak pernah mengalami sakit selama 6 bulan terakhir sebesar 14 orang atau sekitar 48,28 \%. Dengan demikian maka informal yang melakukan aktivitas sebagai pembuat batu merah dapat mencetak batu merah yang lebih banyak dan penghasilan yang lebih besar dibandingkan dengan informal yang mengalami kondisi badan yang kurang sehat. 
Tabel. 4.4.

Tempat Berobat Sebelum Menekuni Pekerjaan Pembuatan Batu Merah

\begin{tabular}{clccc}
\hline No & \multicolumn{1}{c}{ Variabel } & Frekuensi (F) & Persentase (\%) \\
\hline \multirow{3}{*}{4} & a. Di rumah sakit/Puskesmas & 5 & 17,24 \\
\cline { 2 - 4 } & b. Di rumah dukun atau paranormal & 5 & 17,24 \\
\cline { 2 - 4 } & c. Di rumah sendiri & 5 & 17,24 \\
\hline \multicolumn{2}{c}{ Total } & 15 & 100,00 \\
\hline
\end{tabular}

Sumber : Data yang di olah peneliti tahun 2018

Tabel 4.4. di atas terlihat bahwa umumnya informal sebelum menekuni pekerjaan sebagai pembuat batu merah tempat berobat yang mereka pilih adalah bervariasi. Tempat berobat yang mereka pilih adalah Puskesmas dan rumah sendiri masing-masing sebesar 10 orang atau sekitar $34,48 \%$. Sisanya sebanyak 5 orang atau sekitar $17,24 \%$ tempat berobat yang mereka pilih adalah rumah dukun.

Akan tetapi, setelah mereka beraktivitas sebagai pembuat batu merah tempat berobat yang mereka pilih justru berubah secara drastis, seperti yang disajikan oleh Tabel 5.5 berikut :

Tabel 4.5.

Jika Anda Atau Keluarga Anda Menderita Sakit, Tempat Berobat Setela Menekuni Pekerjaan Membuat Batu Bata

\begin{tabular}{clcc}
\hline No & \multicolumn{1}{c}{ Variabel } & Frekuensi (F) & Persentase (\%) \\
\hline \multirow{3}{*}{5} & a. Di rumah sakit/Puskesmas & 26 & 89,65 \\
\cline { 2 - 4 } & b. Di rumah dukun atau paranormal & 1 & 3,45 \\
\cline { 2 - 4 } & c. Di rumah sendiri & 2 & 6,90 \\
\hline \multicolumn{2}{c}{ Total } & 29 & 100,00 \\
\hline
\end{tabular}

Sumber : Data yang di olah peneliti tahun 2018

Tabel 4.4. di atas memperlihatkan bahwa setelah informan bekerja sebagai pembuat batu merah, tempat berobat yang berhubungan dengan kesehatan badan mereka umumnya memilih "Rumah Sakit / Puskesmas" sebesar 26 orang atau sekitar $89,65 \%$. Hanya 2 orang responden atau sekitar $6,90 \%$ saja yang memilih tempat berobat di rumah sendiri, dan mereka yang berobat di rumah dukun atau paranormal hanya 1 orang atau sekitar $3,45 \%$. Keadaan ini dapat prediksi bahwa informal dalam melakukan aktivitas keseharian telah memperhatikan kesehatan kerja.

Tabel 4.6.

Yang Memberi Pertolongan Saat Anda Sakit, Sebelum Anda Menekuni Pekerjaan Membuat Batu Merah

\begin{tabular}{cllcc}
\hline No & \multicolumn{1}{c}{ Variabel } & Frekuensi (F) & Persentase (\%) \\
\hline \multirow{2}{*}{6} & a. Dokter & 5 & 17,24 \\
\cline { 2 - 5 } & b. Tenaga medis yang bukan dokter & 19 & 65,52 \\
\cline { 2 - 5 } & c. Dukun & 5 & 17,24 \\
\hline \multicolumn{2}{c}{ Total } & 29 & 100,00 \\
\hline
\end{tabular}


Sumber : Data yang di olah peneliti tahun 2018

Keadaan lain di mana informal sebelum menekuni pekerjaan sebagai pembuat batu merah pada saat mengalami kondisi badan kurang sehat atau sakit umumnya informal ditolong oleh tenaga dokter yang "bukan" dokter sebanayak 19 orang atau sekitar $65,52 \%$. Hanya 5 orang atau sekitar $17,24 \%$ yang ditolong oleh dukun dan juga 5 orang atau sekitar $17,24 \%$ yang ditolong oleh tenaga dokter. Perlu penulis jelaskan bahwa di Desa dimana penelitian ini dilakukan bahwa untuk mendapatkan pelayanan dari seorang dokter dapat dikatakan relatif sulit dan terkendala juga tentang biaya yang dikenakan pada mereka sebagai pasien, sehingga pemanfaatan dukun sebagai salah satu alternatif tidak bisa dihindari, apalagi pembiayaan untuk itu bolah dikatakan terjangkau.

Tabel 4.7.

Yang Memberi Pertolongan Saat Anda Sakit, Setelah Anda Menekuni Pekerjaan Membuat Batu Merah

\begin{tabular}{cllcc}
\hline No & \multicolumn{1}{c}{ Variabel } & Frekuensi (F) & Persentase (\%) \\
\hline \multirow{2}{*}{7} & a. Dokter & 23 & 79,31 \\
\cline { 2 - 5 } & b. Tenaga medis yang bukan dokter & 6 & 20,69 \\
\cline { 2 - 5 } & c. Dukun & - & - \\
\hline \multicolumn{2}{c}{ Total } & 29 & 100,00 \\
\hline
\end{tabular}

Sumber : Data yang di olah peneliti tahun 2018

Berbeda dengan muatan isi yang disajikan oleh Tabel 5.6, di mana muatan isi dari Tabel 4.7 di atas menyajikan keadaan sebaliknya. Berdasarkan Tabel 5.7 tersebut dapat dikatakan bahwa setelah informal menekuni pekerjaan sebagai pembuat batu merah ternyata pertolongan yang berasal dari tenaga medis (dokter) yang lebih dominan yaitu sebanayak 23 orang atau sekitar 79,31\%, dibandingkan dengan tenaga medis yang bukan dokter sebanyak 6 orang atau sekitar 20,69\% dan tenaga dukun di sini sudah terabaikan.

\section{Kondisi Perumahan (Tempat Tinggal)}

Kondisi rumah diperlukan sebagai salah satu indikator kondisi sosial masyarakat sebagai responden dikemukakan sebanyak 7 (tujuh) item pernyataan yang disajikan oleh Tabel 4.8; Tabel 4.9; Tabel 4.10; Tabel 4.11; Tabel 4.12; Tabel 4.13; dan Tabel 4.14 yang dapat dikemukakan sebagai berikut : 
Tabel 4.8.

Status Rumah Yang Anda Tempati, Sebelum Menekuni Pekerjaan Pembuatan Batu Merah

\begin{tabular}{cllcc}
\hline No & \multicolumn{1}{c}{ Variabel } & Frekuensi (F) & Persentase (\%) \\
\hline \multirow{2}{*}{8} & a. Rumah kontrakan & 5 & 17,24 \\
\cline { 2 - 4 } & b. Rumah keluarga/familih & 17 & 58,62 \\
\cline { 2 - 4 } & c. Rumah hak milik & 7 & 24,14 \\
\hline \multicolumn{2}{c}{ Total } & 29 & 100,00 \\
\hline
\end{tabular}

Sumber : Data yang di olah peneliti tahun 2018

Keadaan yang berkenaan dengan perumahan (rumah sebagai tempat tinggal) dapat dikatakan bahwa "sebelum" informan menekuni pekerjaan sebagai pembuat batu merah, umumnya informan tinggal di rumah keluarga (famili) sebesar 17 orang atau sekitar 58,62\%. Disamping menempati rumah keluarga, mereka juga tinggal di rumah kontrakan sebesar 5 orang atau sekitar 17,24\%. Bagi responden yang tinggal atau menempati rumah sendiri sebanyak 7 orang atau sekitar $24,14 \%$
Berdasarkan kenyataan di Tabel 5.8 tersebut terungkap bahwa informal yang menempati rumah keluarga atau familih ini ternyata mereka termasuk yang baru beberapa bulan "berumah tangga". Wajarlah kalau informal yang berada di wilayah Perdesaan, belum memiliki kemampuan yang memadai untuk memiliki rumah sebagai tempat tunggal.

Tabel 4.9.

Status Rumah Yang Anda Tempati, Setelah Menekuni Pekerjaan Pembuatan Batu Merah

\begin{tabular}{cccc}
\hline No & \multicolumn{1}{c}{ Variabel } & Frekuensi (F) & Persentase (\%) \\
\hline \multirow{3}{*}{9} & a. Rumah kontrakan & 1 & 3,45 \\
\cline { 2 - 4 } & b. Rumah keluarga/familih & 4 & 13,79 \\
\cline { 2 - 4 } & c. Rumah hak milik & 24 & 82,76 \\
\hline \multicolumn{2}{c}{ Total } & 29 & 100,00 \\
\hline \multicolumn{3}{c}{ Sumber : Data yang di olah peneliti tahun 2018}
\end{tabular}

Keadaan yang berkenaan dengan perumahan (rumah sebagai tempat tinggal) dapat dikatakan bahwa "setelah" informan menekuni pekerjaan sebagai pembuat batu merah, umumnya informan tinggal di rumah keluarga (famili) sebesar 4 orang atau sekitar $13,79 \%$. Penempatan rumah kontrakan setelah mereka menekuni pekerjaan sebagai pembuat batu merah telah mengalami pengurangan dari 5 orang atau sekitar $17,24 \%$ menjadi tinggal 1 orang atau sekitar 3,45\%. Selanjutnya, ditemukan bahwa responden yang menempati rumah sendiri sebanyak 7 orang atau sekitar $24,14 \%$ berubah secara drastis menjadi 24 orang responden atau sekitar $82,76 \%$.

Kondisi ini menunjukkan bahwa umumnya responden atau informan setelah menekuni pekerjaan sebagai pembuatan batu merah dapat mebuahkan hasil yang dapat merubah kondisi sosial masyarakat kaitannya 
dengan kepemilikan rumah sebagai tempat tinggal bagi warga masyarakat, seperti data yang disajikan pada Tabel 5.9 tersebut di atas.

Tabel 4.10.

Sumber Penerangan Di Dalam Rumah, Sebelum Menekuni Pembuatan Batu Merah

\begin{tabular}{clcc}
\hline No & \multicolumn{1}{c}{ Variabel } & Frekuensi (F) & Persentase (\%) \\
\hline \multirow{3}{*}{10} & a. P L N & 16 & 55,17 \\
\cline { 2 - 4 } & b. Lampu petromax & 7 & 24,14 \\
\cline { 2 - 4 } & c. Obor atau lampu teplok & 6 & 20,69 \\
\hline \multicolumn{2}{c}{ Total } & 29 & 100,00 \\
\hline \multicolumn{3}{c}{ Sumber : Data yang di olah peneliti tahun 2018}
\end{tabular}

Sebelum informan menekuni pekerjaan sebagai pembuat batu merah, penerangan di dalam rumah bersumber dari PLN sebanyak 16 orang atau sekitar 55,17\%. Informan yang mengunakan lampu petromax sebagai sumber penerangan di dalam rumah sebanayk 7 orang atau sekitar $24,14 \%$ dan informan yang menggunakan obor atau lampu teplok sebagai sumber penerangan di dalam rumah mereka sebanyak 6 orang atau sekitar 20,69\%, seperti yang disajikan oleh Tabel 4.1

Tabel 4.11.

Sumber Penerangan Di Dalam Rumah, Setelah Menekuni Pembuatan Batu Merah

\begin{tabular}{lllc}
\hline No & \multicolumn{1}{c}{ Variabel } & Frekuensi (F) & Persentase (\%) \\
\hline \multirow{3}{*}{11} & a. PLN & 29 & 100 \\
\cline { 2 - 4 } & b. Lampu petromax & - & - \\
\cline { 2 - 4 } & c. Obor atau lampu teplok & - & - \\
\hline \multicolumn{2}{c}{ Total } & 29 & 100,00 \\
\hline
\end{tabular}

Sumber : Data yang di olah peneliti tahun 2018

Berbeda dengan kondisi informan sebelun menekuni pekerjaan sebagai pembuat batu merah, pada Tabel 5.12 dapat ditunjukkan bahwa setelah informan menekuni pekerjaan sebagai pembuat batu merah ditemukan bahwa warga yang menekuni pekerjaan sebagai pembuat batu merah dalam hal penerangan di dalam rumah tidak lagi menggunakan "obor atau lampu teplok" dan "lampu petromax" melainkan seluruhnya sudah menggunakan sumber penerangan yang berasal dari PLN sebagai pemasoknya.

Keadaan ini di duga sebagai akibat keberhasilan responden dalam menekuni pekerjaan sebagai pembuat batu merah seperti yang disajikan oleh Tabel 4.11. 
Tabel 4.12.

Kondisi Bangunan Rumah Yang Anda Tempat, Sebelum Menekuni Pekerjaan Pembuatan Batu Merah

\begin{tabular}{clcc}
\hline No & \multicolumn{1}{c}{ Variabel } & Frekuensi (F) & Persentase (\%) \\
\hline \multirow{2}{*}{12} & a. Semi permanen berlantai tanah & 21 & 72,42 \\
\cline { 2 - 4 } & b. Permanen berlantai tanah & 4 & 13,79 \\
\cline { 2 - 4 } & c. Permanen berlantai keramik & 4 & 13,79 \\
\hline \multicolumn{2}{c}{ Total } & 29 & 100,00 \\
\hline
\end{tabular}

Sumber : Data yang di olah peneliti tahun 2018

Tentang kondisi bangunan rumah informal sebelum menekuni pekerjaan sebagai pembuat batu merah ditemukan bahwa terdapat 21 orang responden atau sekitar 72,42 \% menempati "rumah semi permanen yang berlantai tanah". Informan yang kondisi rumahnya "permanen yang berlantai tanah" dan "permanen yang berlantai keramik" masing-masing sebanyak 4 orang atau sekitar 13,79 $\%$. Kondisi menunjukkan bahwa umumnya kondisi bangunan rumah mereka pada umumnya didominasi oleh rumah yang "semi permanen berlantai tanah", seperti yang disajikan oleh Tabel 4.12.

Tabel 4.13.

Kondisi Bangunan Rumah Yang Anda Tempat, Setelah Menekuni Pekerjaan Pembuatan Batu Merah

\begin{tabular}{clcc}
\hline No & Variabel & Frekuensi (F) & Persentase (\%) \\
\hline \multirow{3}{*}{13} & a. Semi permanen berlantai tanah & 4 & 13,80 \\
\cline { 2 - 4 } & b. Permanen berlantai tanah & 15 & 51,72 \\
\cline { 2 - 4 } & c. Permanen berlantai keramik & 10 & 34,48 \\
\hline \multicolumn{2}{c}{ Total } & 29 & 100,00 \\
\hline
\end{tabular}

Sumber : Data yang di olah peneliti tahun 2018

Kondisi bangunan rumah responden setelah menekuni pekerjaan sebagai pembuat batu merah mengalami perubahan ke arah yang lebih baik. Indikatornya adalah bahwa dari 21 responden atau sekitar 72,42 $\%$ yang tadinya memiliki "rumah semi permanen yang berlantai tanah" mengecil menjadi 4 responden atau sekitar 13,80 dari 72,42 \%. Selanjutnya, responden yang kondisi rumahnya "permanen yang berlantai tanah" hanya 4 responden atau sekitar $13,79 \%$ berubah menjadi lebih banyak yaitu terdapat 15 responden atau sekitar $51,72 \%$ dan begitu pula dengan memiliki rumah "permanen yang berlantai keramik" sebesar 4 orang atau sekitar 13,79\% berubah menjadi lebih banyak yanitu 10 responden atau sekitar 34,48 \%. Kondisi tersebut menunjukkan bahwa bangunan rumah mereka yang tadinya didominasi oleh rumah yang "semi permanen berlantai tanah", sekarang mengalami perubahan menjadi rumah permanen berlantai tanah dan rumah permanen berlantai keramik, seperti yang disajikan oleh Tabel 4.13 di atas. 
Tabel 4.14. Sumber Air Bersih Yang di Gunakan Oleh Informan

\begin{tabular}{cllcc}
\hline No & \multicolumn{1}{c}{ Variabel } & Frekuensi (F) & Persentase (\%) \\
\hline \multirow{3}{*}{14} & a. & Sumur gali & 29 & 100 \\
\cline { 2 - 4 } & b. Sumur bor & - & - \\
\cline { 2 - 4 } & c. & PDAM & - & - \\
\hline \multicolumn{2}{c}{} & Total & 29 & 100,00 \\
\hline \multicolumn{4}{c}{ Sumber : Data yang di olah peneliti tahun 2018}
\end{tabular}

Keadaan sumber air bersih yang diperoleh warga pembuat batu merah pada umumnya diperoleh dari sumur gali. Keadaan ini dapat dimaklumi, karena kondisi geomorfologi dan geologi di wilayah Desa Kalibu Kecamatan Kulisusu Kabupten Buton Utara sementara dalam penelitian oleh Dinas Pertambangan.

\section{Mata Pencaharian dan Pendapatan}

Tabel 4. 15.

Pekerjaan Utama Anda Sebelum Menekuni Profesi Sebagai Pembuat Batu Merah

\begin{tabular}{clcc}
\hline No & \multicolumn{1}{c}{ Variabel } & Frekuensi (F) & Persentase (\%) \\
\hline \multirow{3}{*}{15} & a. Tani & 12 & 41,38 \\
\cline { 2 - 4 } & b. Tukang & 2 & 6,90 \\
\cline { 2 - 4 } & c. Tidak menentu & 15 & 51,72 \\
\hline \multicolumn{2}{c}{ Total } & 29 & 100,00 \\
\hline
\end{tabular}

Sumber : Data yang di olah peneliti tahun 2018

Tabel 4.15 tersebut di atas menggambarkan bahwa responden (informal) sebelum menekuni pekerjaan sebagai pembuat batu merah memiliki pekerjaan yang "tidak menentu" yaitu 15 orang atau sekitar $51,72 \%$. Responden yang pekerjaannya sebagai petani sebelum menekuni pekerjaan sebagai pembuat batu merah sebanyak 12 orang atau sekitar $41,38 \%$. Sisanya sebanyak 2 orang atau sekitar $6,90 \%$ berprofesi sebagai tukang (dalam hal ini tukang batu dan tukang kayu). Berdasarkan hasil wawancara yang dilakukan peneliti, dapat diketahui bahwa penghasilan dari pebekrjaan "yang tidak menentu" tersebut berdampak pada saldo yang relatif kurang atau sedikit.

Tabel 4.16.

Penghasilan Bersih (Netto) Setiap Bulannya, Sebelum Anda Menekuni Pekerjaan Membuat Batu Merah

\begin{tabular}{clccc}
\hline No & \multicolumn{1}{c}{ Variabel } & Frekuensi (F) & Persentase (\%) \\
\hline \multirow{3}{*}{16} & a. 3 rupiah jutaan ke atas & 3 & 10,34 \\
\cline { 2 - 5 } & b. 1,5 jutaan s.d. lebih kecil 3 juta rupiah & 3 & 10,34 \\
\cline { 2 - 5 } & c. Lebih kecil dari 1,5 juta rupiah & 23 & 79,32 \\
\hline \multicolumn{2}{c}{ Total } & 29 & 100,00 \\
\hline
\end{tabular}

Sumber : Data yang di olah peneliti tahun 2018 
Penghasilan netto yang dimiliki responden/informan sebelum menekuni pekerjaan sebagai pembuat batu merah umumnya $<\mathrm{Rp}$ 1.500.000,- sebanyak 23 orang atau sekitar $79,32 \%$, sementara pendapatan antara Rp 1.500.000,- sampai dengan
Rp 3.000.000,- sebanyak 3 orang atau sekitar $10,34 \%$ dan begitu pula dengan penghasilan responden yang jauh lebih besar Rp 3.000.000,- juga dimiliki oleh 3 responden atau sekitar $10,34 \%$ seperti yang disajikan oleh Tabel

Tabel 4.17.

Penghasilan Bersih (Netto) Setiap Bulannya, Sesudah Anda Menekuni Pekerjaan Membuat Batu Merah

\begin{tabular}{ccccc}
\hline \multirow{2}{*}{ No } & Variabel & $\begin{array}{c}\text { Frekuensi } \\
(\mathrm{F})\end{array}$ & Persentase (\%) \\
\hline \multirow{3}{*}{17} & a. $\quad$ 3 rupiah jutaan ke atas & 3 & 10,34 \\
\cline { 2 - 4 } & b. 1,5 jutaan s.d. lebih kecil 3 juta rupiah & 23 & 79,32 \\
\cline { 2 - 4 } & c. Lebih kecil dari 1,5 juta rupiah & 3 & 10,34 \\
\hline \multicolumn{2}{c}{ Total } & 29 & 100,00 \\
\hline
\end{tabular}

Sumber : Data yang di olah peneliti tahun 2018

Tabel 4.17 di atas memperlihatkan penghasilan netto warga sesudah menekuni pekerjaan sebagai pembuat batu merah ternyata mengalami perubahan yang mendasar, dimana terdapat 23 responden atau sekitar $79,32 \%$ yang memiliki penghasilan sebanyak Rp. 1.500.000,- sampai dengan yang lebih kecil dari Rp.
3000.000,- Warga masyarakat yang menekuni pekerjaan batu merah memiliki pendapat netto yang lebih kecil dari Rp. 1.500.000,- sebesar 3 oarang atau sekitar 10,34\% dan begitu pula dengan responden yang memiliki penghasilan netto sebesar Rp. 3.000.000, ke atas adalah 3 orang atau sekitar $10,34 \%$.

Tabel 4. 18. Jumlah Beban Anggota Keluarga Yang Anda Tanggung

\begin{tabular}{ccccc}
\hline No & Variabel & Frekuensi (F) & Persentase $(\%)$ \\
\hline \multirow{3}{*}{18} & a. 2 orang & 6 & 20,69 \\
\cline { 2 - 4 } & b. 3 orang & 15 & 51,72 \\
\cline { 2 - 4 } & c. $\geq 4$ orang & 8 & 27,59 \\
\hline \multicolumn{2}{c}{ Total } & 29 & 100,00 \\
\hline
\end{tabular}

Sumber : Data yang di olah peneliti tahun 2018

Jumlah anggota keluarga yang menjadi beban tanggunngan saat penelitian ini dilakukan adalah 3 orang sebanyak 15 responden atau sekitar $51,72 \%$, yang menanggung 2 orang adalah 6 responden atau sekitar 20,69 $\%$ dan menanggung sebanyak $\geq 4$ orang sebanyak 8 responden atau sekitar $27,59 \%$. 
Tabel 4.19.

Dana Anggota Keluarga Yang Dikeluarkan Tiap Bulannya, Sebelum Anda Menekuni Pekerjaan Pembuatan Batu Merah

\begin{tabular}{clccc}
\hline No & \multicolumn{1}{c}{ Variabel } & Frekuensi (F) & Persentase (\%) \\
\hline \multirow{2}{*}{19} & a. 3 rupiah jutaan ke atas & - & - \\
\cline { 2 - 5 } & b. 1,5 jutaan s.d. lebih kecil 3 juta rupiah & 4 & 13,79 \\
\cline { 2 - 5 } & c. Lebih kecil dari 1,5 juta rupiah & 25 & 86,21 \\
\hline \multicolumn{2}{c}{ Total } & 29 & 100,00 \\
\hline
\end{tabular}

Sumber : Data yang di olah peneliti tahun 2018

Tabel 4.19 memperlihatkan tentang besarnya dana yang dikeluarkan responden sebelum menekuni pekerjaan sebagai pembuat batu merah, yaitu : terdapat 25 responden atau sekitar 86,21 \% mereka mengeluarkan dana tiap bulan untuk pemenuhan kebutuhan keluarga sebesar "lebih kecil Rp 1.500.000,Sementara itu, terdapat 4 responden atau sekitar 13,79\% mengeluarkan dana bagi pemenuhan kebutuhan anggotan keluarga sebesar Rp 1.500.000, sampai dengan Rp 3.000.000,- Dari Tabel 5.19 tersebut ditemukan bahwa tidak ada warga sebagai pembuat batu merah yang mengeluarkan dana anggota keluar setiap bulan yang lebih besar atau sama dengan Rp 3.000.000, ( $\geq \mathrm{Rp}$ 3.000.000,-)

Tabel 4.20.

Dana Anggota Keluarga Yang Dikeluarkan Tiap Bulannya, Setelah Anda Menekuni Pekerjaan Pembuatan Batu Merah

\begin{tabular}{cllcc}
\hline No & Variabel & Frekuensi (F) & Persentase (\%) \\
\hline \multirow{2}{*}{20} & a. 3 rupiah jutaan ke atas & 4 & 13,79 \\
\cline { 2 - 5 } & b. 1,5 jutaan s.d. lebih kecil 3 juta rupiah & 20 & 68,97 \\
\cline { 2 - 5 } & c. $\quad$ Lebih kecil dari 1,5 juta rupiah & 5 & 17,24 \\
\hline \multicolumn{2}{c}{ Total } & 29 & 100,00 \\
\hline
\end{tabular}

Sumber : Data yang di olah peneliti tahun 2018

Berangkat dari data pada Tabel 5.20 dapat dikatakan bahwa terdapat 20 responden atau sekitar 68,97 \% responden mengeluarkan dana keluarga tiap bulannya sebesar Rp 1,5 juta s.d. < Rp 3 juta. Informan sebagai pembuat batu merah telah mengeluarkan dana keluarga tiap bulannya lebih kecil $\mathrm{Rp} 1,5$ juta. Sementara informan atau responden yang mampu mengeluarkan dana keluarga tiap bulan sebesar Rp 3.000.000,- adalah 4 orang atau sekitar $13,79 \%$.
Data yang tercantum pada Tabel 5.20 di atas menunjukkan bahwa ada perubahan pengeluaran setiap responden untuk memenuhi kebutuhan anggota keluarganya setiap bulan. Pada saat informan/responden sebelum menekuni pekerjaan sebagai pembuat batu merah dapat mengeluarkan dana paling tinggi sebesar Rp 1.500.000, namun setelah mereka bekerja atau menekuni pekerjaan sebagai pembuat batu merah sudah bisa mengeluarkan 
dana Rp 1.500.000, hingga mencapai nominal angka Rp 3.000.000,-

Disamping itu ditemukan pula bahwa sebelum responden berprofesi sebagai pembuat batu merah "tidak satupun" responden mengeluarkan dana di atas Rp 3.000.000,- namun setelah responden berprofesi sebagai pembuat batu merah ada 4 responden yang mengeluarkan dana keluarga yang jauh lebih besar dari $\mathrm{Rp}$ 3.000.000,-

\section{KESIMPULAN}

Berangkat dari rumusan permasalahan yang dikemukakan di bab I dan hasil penelitian serta pembahasan pada bab V, maka penulis menyampai beberapa kesimpulan yang dapat dikemukakan sebagai berikut :

1. Gambaran tentang

kondisikehidupan sosial warga masyarakat di Desa Kalibu kaitannya dengan pembuatan batu merah ternyata lebih baik dibanding mereka sebelum menekuni industri batu merah. Walaupun tingkat pendidikan umumnya tamat SD dan SMP saja, namun mereka dapat melakukan pekerjaan sebagai pekerja pencetak batu merah. Dengan menekuni pekerjaan ini biaya kesehatan anggota keluarga dapat terpenuhi. Kondisi rumah informan umumnya berubah lebih baik dari perolehan hasil sebagai pembuat batu merah. Informan juga dapat menyekolahkan anaknya sampai perguruan tinggi sebagai dampak dari keberhasilan dalam menekuni industri pembuatan batu merah;

2. Gambaran tentang kondisi kehidupan ekonomi warga masyarakat di Desa Kalibu kaitannya dengan pembuatan batu merah adalah membaik. Hal ini dibuktikan dengan meningkatnya pendapatan informan mencapai hampir Rp 3.000.000,- yang sebelum menekuni pekerjaan sebagai pembuat batu merah sebesar $\leq \mathrm{Rp} 1.500 .000,-$ Besarnya dana yang dikeluarkan setelah menekuni industri pembuatan batu merah pada umumnya bervariasi dan tergantung kebutuhan yang mendesak. Nilai nominal dana pengeluaran itu berkisar antara $\mathrm{Rp}$ 1.500.000,- sampai dengan $\mathrm{Rp}$ 2.000.000,- ;

3. Pembuatan batu merah yang dilakukan informan/responden umumnya dapat menopang kehidupan sosial ekonomi warga masyarakat di Desa Kalibu Kecamatan Kulisusu Kabupaten Buton Utara.

Berangkat dari kesimpulan penelitian yang dikemukakan di atas maka penulis mengemukakan beberapa saran sebagai berikut :

1. Sehubungan dengan kegiatan industri batu merah di wilayah Kecamatan Kulisusu, maka pemerintah setempat hendaknya memberi dukungan berupa bantuan peralatan cetak batu merah sehingga hasil cetakan batu merah oleh warga masyarakat lebih terjamin kualitasnya;

2. Pemerintah setempat harus selalu memonitor warga yang pekerjaannya pembuat batu merah agar menjaga kelestarian lingkungan. Untuk diketahui bahwa batu merah dibuat dari bahan tanah. Jadi, penggunaan sumberdaya lahan sebaiknya memperhatikan kaidah-kaidah lingkungan. 


\title{
DAFTAR PUSTAKA
}

\author{
Abdulsyani. 2001. Sosiologi \\ Skematika, Teori dan \\ Terapan. Jakarta : \\ Bumi Akasara. \\ BPS (2001). Perkembangan Tingkat \\ Kesejahteraan Penduduk \\ Perdesaan. Jakarta - \\ Indonesia, BPS.
}

Soemantri Ating dan Muhidin Sambas Ali (2006). Aplikasi dalam Penelitian. Bandung, Rosdakarya.

Purwanto. 1987. Ilmu Pendidikan Teoritis dan Praktis.

Penerbit

PT. Remaja Rosda Karya. Bandung

Soekanto.1988. Teori Sosiologi

Tentang Dinamika Perubahan Sosial. Ghalia. Jakarta.

Soekanto (1983). Teori Sosiologi Tentang Struktur. Jakarta, CV Rajawali.
Sukirno (2003). Ekonomi Pembangunan. Jakarta, BPFE UI.

Winardi (1992). Ilmu Ekonomi. Bandung, Tarsito. 